\title{
Prevalence of and risk factors for periodontal disease among pregnant women in an antenatal care clinic in Khartoum, Sudan
}

\author{
Yasir Salih', Abubakr M. Nasr ${ }^{1}$, Abdel B. A. Ahmed², Manal E. Sharif ${ }^{2}$ and Ishag Adam ${ }^{\text {* }}$
}

\begin{abstract}
Objectives: The aim was to investigate the prevalence of and factors associated with periodontal disease among pregnant Sudanese women. A cross-sectional study was conducted at the Antenatal Care Clinic of Saad Abualila Hospital (Khartoum, Sudan) from August to October 2018. Socioeconomic-demographic information and reproductive history were gathered using a questionnaire. Body mass index was computed from the weight and height. The diagnosis of periodontal disease was performed using criterion that also evaluated bleeding upon probing.

Results: Four hundred and four women were enrolled in the study, with a mean (SD) gestational age of 30.0 (8.7) weeks. Their mean (SD) age and parity were 27.0 (5.7) years and 1.6 (1.7), respectively. Ninety-seven (24.0\%) of these 404 women had periodontal disease, which was mild, moderate and severe in 49 (12.1\%), 36 (8.9\%) and 12 (3.0\%) women respectively, while 307 (76.0\%) women had no periodontal disease. In logistic regression, age, parity, education, and brushing were not associated with periodontitis, but lower gestational age was associated with periodontal disease $(\mathrm{OR}=0.96,95 \% \mathrm{Cl} 0.94-0.99, \mathrm{P}=0.011)$.
\end{abstract}

Keywords: Periodontal disease, Pregnancy, Risk factors, Sudan

\section{Introduction}

Periodontal disease is an inflammatory process/condition of the soft tissues that surround the teeth characterized by gradual destruction of the soft tissue that supports the structures of the teeth [1]. Periodontal disease is an infectious disease distributed worldwide that can affect up to $90 \%$ of populations [2, 3]. Poor oral hygiene, increasing age, smoking, low educational level, some ethnicities, and poor economic status have been reported as risk factors for periodontal disease [1-4].

During pregnancy, due to hormonal factors (high oestrogen and progesterone), women are more vulnerable to periodontal disease than their non-pregnant peers [5]. Pregnant women with periodontal disease are more

\footnotetext{
${ }^{*}$ Correspondence: ishagadam@hotmail.com

${ }^{1}$ Faculty of Medicine, University of Khartoum, PO box 102, Khartoum, Sudan

Full list of author information is available at the end of the article
}

susceptible to poor maternal and perinatal outcomes such as preeclampsia [6], gestational diabetes [7], vulvovaginitis, preterm labour, foetal growth restriction [8], low birth weight [9] and perinatal mortality [10].

The prevalence of periodontal disease among pregnant women varies in different populations [11-13]. Moreover, several factors such as age, parity, lower level of education and anaemia were identified as risk factors for periodontal disease during pregnancy $[4,14]$. While there is a large amount of data on periodontal disease during pregnancy in other African countries [12, 15, 16], there is no data on periodontal disease during pregnancy in Sudan. There are high rates of maternal and perinatal adverse outcomes in Sudan [17]. Hence, there is a need to investigate the epidemiology of periodontal disease to yield the basic data necessary for the treating physician as well as health planners. The current study was conducted at the antenatal clinic in Saad Abualila Hospital

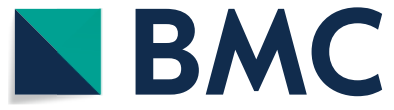

(c) The Author(s) 2020. This article is licensed under a Creative Commons Attribution 4.0 International License, which permits use, sharing, adaptation, distribution and reproduction in any medium or format, as long as you give appropriate credit to the original author(s) and the source, provide a link to the Creative Commons licence, and indicate if changes were made. The images or other third party material in this article are included in the article's Creative Commons licence, unless indicated otherwise in a credit line to the material. If material is not included in the article's Creative Commons licence and your intended use is not permitted by statutory regulation or exceeds the permitted use, you will need to obtain permission directly from the copyright holder. To view a copy of this licence, visit http://creativeco mmons.org/licenses/by/4.0/. The Creative Commons Public Domain Dedication waiver (http://creativecommons.org/publicdomain/ zero/1.0/) applies to the data made available in this article, unless otherwise stated in a credit line to the data. 
(Khartoum, Sudan) to investigate the prevalence of and risk factors for periodontal disease.

\section{Main text \\ Methods \\ Study design and setting}

A cross-sectional study was conducted at the Antenatal Care Clinic of Saad Abualila Hospital (Khartoum, Sudan) from August to October 2018.

\section{Section of participants}

Pregnant women with singleton pregnancy attending the antenatal care clinic for the first time were approached to be enrolled in the study. Socio-demographic, medical and obstetric history (including history of miscarriage and preterm delivery) was gathered through a questionnaire; then, women were asked specifically about teeth brushing (including number of brushing times) and antibiotic usage during the index pregnancy.

\section{Measures}

Body mass index (BMI) was computed from the measured weight and height. The dental examination was performed by a single calibrated examiner in the clinic using a dental chair with adequate lighting via an overhead light. Because the participants were pregnant, dental radiographs were not taken. During the examination, probing was performed at six sites per tooth. The pocket depth (the deepest measurement) was identified for each assessed tooth. Pregnant women were diagnosed as having healthy gingiva if no pocketing and no bleeding on probing were noted. We used the minimum diagnostic criteria for periodontal disease in the current study as follows: "bleeding on probing and a pocket depth of at least $4 \mathrm{~mm}$ and clinical attachment loss of $\geq 6 \mathrm{~mm}$, calculus with plaque deposits, and gingival recession" [18]. The moderate and severe forms of periodontal disease were defined as the presence of 4 or more sites with a pocket depth $>3 \mathrm{~mm}$ and 4 or more sites with pocket depth $\geq 5 \mathrm{~mm}$, respectively. Otherwise, periodontal disease was considered mild.

The sample size was calculated based on a $31.0 \%$ prevalence of periodontal disease during pregnancy in a previous study [13]. A total sample size of 404 women was calculated using a single population proportion formula; this sample size will yield a 95\% confidence interval, precision of $5.0 \%$ and $80 \%$ power.

\section{Statistical analysis}

Data were entered into a computer database and SPSS software (SPSS Inc., Chicago, IL, USA, version 16.0) and double checked before analysis. Means and proportions for the socio-demographic characteristics were compared between the groups of women who had periodontal disease and women who had no periodontal disease using Student's $t$ test and the $\chi^{2}$ test, respectively. Logistic regression analyses were performed using periodontal disease as the dependent variable and sociodemographic characteristics as independent variables. Confidence intervals of 95\% were calculated, and $P<0.05$ was considered significant.

\section{Results}

Four hundreds and four women were enrolled in the study, with a mean (SD) gestational age of 30.0 (8.7) weeks. The mean (SD) age and parity of the investigated women was 27.0 (5.7) years and 1.6 (1.7), respectively. Over one-third (39.0\%) of these women had less than a secondary school education level, Table 1.

Of the 404 women, 73 (18.1\%), $253(62.6 \%)$ and 78 (19.3\%) were brushing only once, twice and more than twice per day, respectively. Out of these 404 women, 45 (11.1\%) had gingival enlargement and only two $(0.5 \%)$ had pregnancy eruption. Ninety-seven $(24.0 \%)$ of these 404 women had periodontal disease, which was mild in $49(12.1 \%)$, moderate in $36(8.9 \%)$ and severe in $12(3.0 \%)$. The other 307 (76.0\%) had no periodontal disease.

Age, parity, education, history of preterm labour, and brushing were not significantly different between the two groups, but gestational age was significantly lower in women with periodontal disease than in women who had no periodontal disease [27.8 (9.8) vs. 30.7 (8.2), $\mathrm{P}=0.004$, Table 2].

Likewise, in logistic regression, age, parity, education, and brushing were not associated with periodontitis, but lower gestational age was associated with periodontal disease $(\mathrm{OR}=0.96,95 \% \mathrm{CI} 0.94-0.99, \mathrm{P}=0.011$, Table 3$)$.

Table 1 Basic socio-demographic characteristics of women $(n=404)$ who were enrolled in the study

\begin{tabular}{lr}
\hline Variable & \\
\hline Mean (SD) of the & $27.0(5.7)$ \\
Age, years & $1.6(1.7)$ \\
Parity & $30.0(8.7)$ \\
Gestational age, weeks & $24.2(3.8)$ \\
Body mass index, kg/m² & \\
Number (proportion) of the & $157(38.8)$ \\
Educational < secondary level & $85(21.3)$ \\
History of miscarriage & $14(3.4)$ \\
History of preterm delivery & $73(18.1)$ \\
Brushing once & $253(62.6)$ \\
Twice & $78(19.3)$ \\
More than twice & $51(12.6)$ \\
Antibiotic usage &
\end{tabular}


Table 2 Comparing socio-demographic characteristics of women who had periodontal disease and women who had no periodontal disease

\begin{tabular}{|c|c|c|c|}
\hline Variable & $\begin{array}{l}\text { Women who had periodontal disease } \\
(\mathrm{n}=97)\end{array}$ & $\begin{array}{l}\text { Women who had no periodontal disease } \\
(n=307)\end{array}$ & $\mathbf{P}$ \\
\hline Age, years & $27.1(5.8)$ & $26.8(5.6)$ & 0.578 \\
\hline Parity & $1.6(1.7)$ & $1.4(1.5)$ & 0.200 \\
\hline Gestational age, weeks & $27.8(9.8)$ & $30.7(8.2)$ & 0.004 \\
\hline Education $<$ secondary level & $31(32.0)$ & $126(41.0)$ & 0.121 \\
\hline History of miscarriage & $23(23.7)$ & $62(20.2)$ & 0.476 \\
\hline History of preterm delivery & $3(3.1)$ & $11(3.6)$ & 0.830 \\
\hline Brushing once & $13(13.4)$ & $60(19.5)$ & 0.313 \\
\hline Twice & $62(64.0)$ & $191(62.2)$ & \\
\hline More than twice & $22(22.7)$ & $56(18.2)$ & \\
\hline Antibiotic usage & $16(16.5)$ & $35(11.4)$ & 0.219 \\
\hline Body mass index, $\mathrm{kg} / \mathrm{m}^{2}$ & $24.3(3.5)$ & $24.1(4.1)$ & 0.067 \\
\hline
\end{tabular}

Table 3 Factors associated with periodontal disease according to logistic regression analyses

\begin{tabular}{llll}
\hline Variable & OR & $\mathbf{9 5 \%} \mathbf{C l}$ & $\mathbf{P}$ \\
\hline Age, years & 0.99 & $0.94-1.04$ & 0.773 \\
Parity & 0.92 & $0.77-1.10$ & 0.388 \\
Gestational age <30 weeks & 0.96 & $0.94-0.99$ & 0.011 \\
Educational level < secondary & 0.67 & $0.40-1.13$ & 0.139 \\
History of miscarriage & 0.85 & $0.47-1.52$ & 0.595 \\
History of preterm delivery & 0.89 & $0.62-1.29$ & 0.566 \\
Brushing & 1.30 & $0.88-1.93$ & 0.176 \\
Antibiotic usage & 0.64 & $0.32-1.25$ & 0.195 \\
Body mass index, $\mathrm{kg} / \mathrm{m}^{2}$ & 1.00 & $0.89-1.12$ & 0.953 \\
\hline
\end{tabular}

\section{Discussion}

The main findings of the current study were that there was a high $(24.0 \%)$ prevalence of periodontal disease among pregnant Sudanese women and that periodontal disease was associated with decrease gestational age. A low (14.2\%) prevalence of periodontal disease was recently reported among pregnant Tanzanian women [12]. Likewise, Gomes-Filho el al. reported a low prevalence $(17.24 \%)$ of periodontal disease among pregnant women in Brazil [19]. A slightly higher prevalence (31\%) of periodontal disease was documented in pregnant women in Jordan [13]. Interestingly, Govindasamy et al. recently reported that over half $(54.8 \%)$ of postpartum women in India had periodontal diseases [11]. Moreover, much higher rates $(84.7 \%$ and $73.9 \%)$ of periodontal disease were reported among women of childbearing age (preconception) in China [20, 21]. Generally, periodontal disease affects between $20 \%$ and $50 \%$ of pregnant women in industrialized areas [22, 23]. It is worth mentioning that our results should be compared to the results of the latter studies with caution because different methods for diagnosing periodontal disease were followed. Previous studies have revealed that estimates of the prevalence of periodontal conditions and their severity as well as the associated factors vary according to the method used in the particular study [24].

Our study showed no association of age, parity, education or tooth brushing with periodontal disease. In China none of the investigated factors were associated with women of childbearing age, and self-reported bleeding during tooth brushing was the only factor associated with periodontal disease [adjusted odds ratio (aOR): 3.71] [21]. A previous study showed that age (over 30 years) and high parity were associated with periodontal disease during pregnancy [14]. Moreover, higher maternal age and parity were reported to be associated with periodontal disease during pregnancy in Uganda [25]. Moreover, educational level, alcohol consumption, overweight and teeth brushing were associated with periodontal disease in women of childbearing age (preconception) in China [20]. Older age, a lower level of education and unemployment were factors associated with periodontal disease in pregnant women in Bangladesh [4]. The difference between our results and the findings of previous studies could be explained by the different cultures and other socio-demographic variables in the different settings and communities.

The current study found no association between BMI and periodontal disease. Recently, Gomes-Filho el al. reported no association between obesity and periodontal disease among pregnant women in Brazil [19]. On the other hand, Lee et al. reported a significant association between obesity and periodontitis in pregnant women [26]. Although an inflammatory process triggered by a bacterial infection is the main factor involved in periodontal disease, 
a variety of other factors such as age, nutrition, smoking and genetic susceptibility can influence the progression/ severity of the disease [1]. It is worth to be mentioned that our results were mainly on the non- adjusted OR of the logistic regression.

\section{Conclusions}

The current study showed a high prevalence of periodontal disease, which showed no association with, age, parity or BMI. Further research on the maternal and perinatal outcomes and periodontal disease is needed. Moreover the outcome of the treatment of periodontal disease needs to be assessed among pregnant Sudanese women.

\section{Limitations of the study}

We failed to follow up these women; hence, the outcomes of the pregnancies were not known. This was a crosssectional study and a cause-effect relationship was not determined.

In summary, the current study showed a high prevalence of periodontal disease, which showed no association with, age, parity and BMI.

\section{Abbreviations}

BMI: Body mass index; OR: Odds ratio; SD: Standard deviation.

\section{Acknowledgements}

The authors would like to thank all women for their participation in the study.

\section{Authors' contributions}

YS, AMN and IA designed the study and participated in drafting the manuscript. ABAA and MES conducted the clinical work. YS, AMN and IA conducted the statistical analyses. All authors read and approved the final manuscript.

\section{Funding}

None.

\section{Availability of data and materials}

The datasets used and/or analysed during the current study are available from the corresponding author on reasonable request.

\section{Ethics approval and consent to participate}

The study received ethical clearance from the Department of Obstetrics and Gynecology, Faculty of Medicine, University of Khartoum, Sudan (2017/07), in accordance with the Declaration of Helsinki. Each woman signed an informed consent form before to be enrolled in the study.

\section{Consent for publication}

Not applicable.

\section{Competing interests}

The corresponding author $(\mathrm{IA})$ is one of the associate editors of the journal.

\section{Author details}

${ }^{1}$ Faculty of Medicine, University of Khartoum, PO box 102, Khartoum, Sudan.

${ }^{2}$ College of Medicine, King Khalid University, Abha, Kingdom of Saudi Arabia.

Received: 4 February 2020 Accepted: 5 March 2020

Published online: 11 March 2020

\section{References}

1. Periodontal Disease Fact Sheet | Perio.org American Academy of Periodontology_Perio.org. IL. Chicago 2017. https://www.perio.org/newsr oom/periodontal-disease-fact-sheet. Accessed 4 Dec 2019.

2. Helmi MF, Huang H, Goodson JM, Hasturk H, Tavares M, Natto ZS. Prevalence of periodontitis and alveolar bone loss in a patient population at Harvard School of Dental Medicine. BMC Oral Health. 2019;19:254-65. https://doi.org/10.1186/s12903-019-0925-z.

3. Pihlstrom BL, Michalowicz BS, Johnson NW. Periodontal diseases. Lancet. 2005;366:1809-20.

4. Anwar N, Zaman N, Nimmi N, Chowdhury TA, Khan MH. Factors associated with periodontal disease in pregnant diabetic women. Mymensingh Med J. 2016;25:289-95.

5. Tettamanti L, Lauritano D, Nardone M, Gargari M, Silvestre-Rangil J, Gavoglio P, et al. Pregnancy and periodontal disease: does exist a twoway relationship? ORAL Implantol. 2017;10:112-8.

6. Khalighinejad N, Aminoshariae A, Kulild JC, Mickel A. Apical periodontitis, a predictor variable for preeclampsia: a case-control study. J Endod. 2017:43:1611-4.

7. Kumar A, Sharma DS, Verma M, Lamba AK, Gupta MM, Sharma S, et al. Association between periodontal disease and gestational diabetes mellitus - a prospective cohort study. J Clin Periodontol. 2018;45:920-31.

8. Figueiredo MGOP, Takita SY, Dourado BMR, de Souza Mendes H, Terakado EO, de Carvalho Nunes HR, et al. Periodontal disease: repercussions in pregnant woman and newborn health-a cohort study. PLoS ONE. 2019;14:e0225036.

9. Mathew RJ, Bose A, Prasad JH, Muliyil JP, Singh D. Maternal periodontal disease as a significant risk factor for low birth weight in pregnant women attending a secondary care hospital in South India: a case-control study. Indian J Dent Res. 2014;25:742-7. https://doi. org/10.4103/0970-9290.152184

10. Bi WG, Emami E, Luo ZC, Santamaria C, Wei SQ. Effect of periodontal treatment in pregnancy on perinatal outcomes: a systematic review and meta-analysis. J Matern-Fetal Neonatal Med. 2019. https://doi. org/10.1080/14767058.2019.1678142.

11. Govindasamy R, Dhanasekaran M, Varghese S, Balaji V, Karthikeyan B, Christopher A. Maternal risk factors and periodontal disease: a crosssectional study among postpartum mothers in Tamil Nadu. J Pharm Bioallied Sci. 2017;9:S50-4.

12. Gesase N, Miranda-Rius J, Brunet-Llobet L, Lahor-Soler E, Mahande MJ, Masenga $G$. The association between periodontal disease and adverse pregnancy outcomes in Northern Tanzania: a cross-sectional study. Afr Health Sci. 2018;18:601-11.

13. Alchalabi HA, Al Habashneh R, Jabali Al O, Khader YS. Association between periodontal disease and adverse pregnancy outcomes in a cohort of pregnant women in Jordan. Clin Exp Obstet Gynecol. 2013:40:399-402

14. Grinin VM, Erkanyan IM, Ivanov SY. Incidence and risk factors of oral diseases in pregnant women. Stomatologiia (Mosk). 2018;97:19-22.

15. Harjunmaa U, Järnstedt J, Alho L, Dewey KG, Cheung YB, Deitchler $M$, et al. Association between maternal dental periapical infections and pregnancy outcomes: results from a cross-sectional study in Malawi. Trop Med Int Health. 2015:20:1549-58. https://doi.org/10.1111/tmi.12579.

16. Muwazi L, Rwenyonyi CM, Nkamba M, Kutesa A, Kagawa M, Mugyenyi G, et al. Periodontal conditions, low birth weight and preterm birth among postpartum mothers in two tertiary health facilities in Uganda. BMC Oral Health. 2014;14:42

17. Ali AA, Okud A, Khojali A, Adam I. High incidence of obstetric complications in Kassala hospital, Eastern Sudan. J Obstet Gynaecol (Lahore). 2012;32:148-9.

18. Armitage GC. Development of a classification system for periodontal diseases and conditions. Northwest Dent. 2000;79:31-5.

19. Gomes-Filho IS, Batista JET, Trindade SC, Passos-Soares JS, Cerqueira EMM, Costa TSD, et al. Obesity and periodontitis are not associated in pregnant women. J Periodontal Res. 2020;55(1):77-84. https://doi.org/10.1111/ jre.12690.

20. Wu YM, Liu J, Sun WL, Chen LL, Chai LG, Xiao X, et al. Periodontal status and associated risk factors among childbearing age women in Cixi City of China. J Zhejiang Univ Sci B. 2013;14:231-9. 
21. Jiang $H$, Su $Y$, Xiong $X$, Harville $E$, Wu H, Jiang $Z$, et al. Prevalence and risk factors of periodontal disease among pre-conception Chinese women. Reprod Health. 2016;13:1-8.

22. Xiong X, Buekens P, Vastardis S, Yu SM. Periodontal disease and pregnancy outcomes: state-of-the-science. Obstet Gynecol Surv. 2007;62:605-15. https://doi.org/10.1097/01.ogx.0000279292.63435.40.

23. Madianos PN, Lieff S, Murtha AP, Boggess KA, Auten RL, Beck JD, et al. Maternal periodontitis and prematurity. Part II: maternal infection and fetal exposure. Ann Periodontol. 2001;6:175-82. https://doi.org/10.1902/ annals.2001.6.1.175

24. Kingman A, Albandar JM. Methodological aspects of epidemiological studies of periodontal diseases. Periodontol. 2000;2002(29):11-30.
25. Wandera M, Astrøm AN, Okullo I, Tumwine JK. Determinants of periodontal health in pregnant women and association with infants' anthropometric status: a prospective cohort study from Eastern Uganda. BMC Pregnancy Childbirth. 2012;12:90.

26. Lee H-J, Jun J-K, Lee S-M, Ha J-E, Paik D-I, Bae K-H. Association between obesity and periodontitis in pregnant females. J Periodontol. 2014;85:e224-31

\section{Publisher's Note}

Springer Nature remains neutral with regard to jurisdictional claims in published maps and institutional affiliations.
Ready to submit your research? Choose BMC and benefit from:

- fast, convenient online submission

- thorough peer review by experienced researchers in your field

- rapid publication on acceptance

- support for research data, including large and complex data types

- gold Open Access which fosters wider collaboration and increased citations

- maximum visibility for your research: over $100 \mathrm{M}$ website views per year

At BMC, research is always in progress.

Learn more biomedcentral.com/submissions 